\title{
Erratum to: ProCoS: How It All Began - as Seen from Denmark
}

\author{
Dines Bjørner
}

\section{Erratum to:}

ProCoS: How It All Began - as Seen from Denmark in: M. Hinchey et al. (eds.), Provably Correct Systems, NASA Monographs in Systems and Software Engineering, DOI 10.1007/978-3-319-48628-4_1

The original version of the book was inadvertently published with old manuscript instead of revised manuscript for Chapter 1. The erratum chapter and the book have been updated with the change.

The updated online version for this chapter can be found at http://dx.doi.org/10.1007/978-3-319-48628-4_1 